\title{
Chronic hypernatraemia and hypothermia following subarachnoid haemorrhage
}

\author{
Stephen S. Nussey, Vincent T.Y. Ang and John S. Jenkins \\ Department of Medicine, St. George's Hospital Medical School, Cranmer Terrace, London SW17 ORE, UK.
}

\begin{abstract}
Summary: We describe a 30 year old man who developed chronic adipsic hypernatraemia and hypothermia following a subarachnoid haemorrhage from an anterior communicating artery aneurysm. Anterior pituitary function tests were normal. Hypothermia was demonstrated over 4 years with loss of the ability to control heat conservation despite body temperatures as low as $30^{\circ} \mathrm{C}$. He failed to experience thirst despite plasma sodium concentrations of up to $187 \mathrm{nmol} / 1$ and plasma osmolalities of up to $397 \mathrm{mOsm} / \mathrm{kg}$. The slope of the plasma vasopressin-plasma osmolality curve indicated loss of the osmoreceptor. There was an absent vasopressin response to insulin-induced hypoglycaemia but a normal response to apomorphine. The apomorphine-stimulated immunoreactive vasopressin was shown to behave identically to the synthetic peptide on HPLC and was bioactive.
\end{abstract}

\section{Introduction}

The hypothalamus is intimately involved in the regulation of both temperature and fluid balance (Plum \& Van Uitert, 1978). It lies close to the circle of Willis and receives its blood supply from many small branches of vessels forming this circle (Crompton, 1963). It is frequently damaged by ruptured aneurysms particularly of the anterior and posterior communicating arteries (Crompton, 1963). Hypernatraemia following rupture of an aneurysm is associated with a high mortality (Takaku et al., 1979). Chronic hypernatraemia is unusual and, when present, is characterized by normal renal function, absence of clinical hypovolaemia and decreased perception of thirst (Halter et al., 1977). Direct assay of plasma arginine vasopressin (AVP) in response to independent stimulation of both osmoreceptor and baroreceptor mechanisms suggested selective osmoreceptor dysfunction as a cause of this syndrome (Halter et al., 1977; Robertson, 1983). However, in these studies the AVP was not characterized beyond immunoreactivity with the antiserum.

We report a patient who developed chronic hypernatraemia and hypothermia following a subarachnoid haemorrhage from an anterior communicating artery aneurysm which was surgically clipped. AVP concentration in the plasma was monitored following in-

Correspondence: S.S. Nussey, D.Phil., M.R.C.P.

Accepted: 6 December 1985 dependent stimulation of both osmoreceptor and nonosmoreceptor (hypoglycaemia and apomorphine) mechanisms for AVP release. In view of recent data illustrating the importance of characterizing immunoreactive neurohypophysial peptides (Amico et al., 1985), we characterized the secreted AVP by HPLC.

\section{Case report}

A 30 year old man with no previous history of hypertension suffered a subarachnoid haemorrhage in April 1981. Computed tomographic (CT) scan and angiography demonstrated an anterior communicating aneurysm and a hypoplastic right anterior cerebral artery. He underwent right frontal craniotomy and clipping of the aneurysm. Postoperatively he was noted to be hypothermic (oral/rectal temperature $34.5-35.5^{\circ} \mathrm{C}$ ) and hypernatraemic (plasma sodium $156 \pm 6.6 \mathrm{mmol} / \mathrm{l}$; mean \pm s.d., $n=19$; range $147-173 \mathrm{mmol} / \mathrm{l})$. Although he ate spontaneously and with normal appetite, he needed encouragement to drink and exhibited little spontaneous thirst even though his plasma sodium and osmolality had risen significantly. Daily urine output when encouraged to drink was 1-2 litres. On occasion he was noted to sweat profusely and to become discomforted in a warm room despite an oral temperature of around $35^{\circ} \mathrm{C}$ and a cool skin. He was a barrister by profession 
but following his recovery from the subarachnoid haemorrhage he behaved childishly and exhibited defects in memory and learning. Psychometric tests were interpreted as showing evidence of frontal lobe damage. Two months after the subarachnoid haemorrhage his plasma thyroxine, diurnal plasma cortisol variation and metyrapone tests were normal. Over the following 3 years he had several admissions to hospital with recurrent hypernatraemia. In 1983 he suffered an episode of muscle weakness associated with hypernatraemia (plasma sodium $187 \mathrm{mmol} / \mathrm{l}$, plasma osmolality $397 \mathrm{mOsm} / \mathrm{kg}$ and urine osmolality $949 \mathrm{mOsm} / \mathrm{kg}$ ) and markedly elevated plasma creatine phosphokinase (4434 IU/l: normal < 270 IU/1). Despite the marked elevation of plasma sodium and osmolality he failed to complain of thirst. Plasma lipids were normal on several occasions.

He was admitted to this hospital in January 1985 in a marked hypothermic state (rectal temperature $=30^{\circ} \mathrm{C}$ ) despite living in modern and wellheated accommodation. Despite his low body temperature he was noted neither to shiver nor to seek a warm place or clothing. His baseline biochemistry was normal but he had a marked thrombocytopenia (platelet count $\left.95 \times 10^{9} / 1\right)$. He responded well to rewarming and his platelet count returned to normal over 10 days. However, he was, again, noted to sweat profusely in a warm room despite a core temperature of around $35^{\circ} \mathrm{C}$. When recovered from his hypothermia and running a temperature of around $35^{\circ} \mathrm{C}$ he underwent a combined intravenous insulin stress test $(0.15 \mathrm{U} / \mathrm{kg})$, thyrotrophin releasing hormone (TRH) test and gonadotrophin releasing hormone (GnRH) test; hypertonic saline infusion and apomorphine test.

\section{Methods}

\section{Anterior pituitary function}

An indwelling needle was inserted into an antecubital vein and 30 minutes later baseline blood samples removed. The line was flushed with small volumes of isotonic saline. After baseline samples had been taken, soluble insulin $(0.15 \mathrm{U} / \mathrm{kg}$ body weight), TRH $200 \mu \mathrm{g}$ and GnRH $100 \mu \mathrm{g}$ were injected and flushed through with isotonic saline. Further samples of blood were taken at $\mathbf{3 0}$ minute intervals via the indwelling line.

\section{Hypertonic saline infusion}

The procedure for obtaining blood samples was similar to that for insulin-induced hypoglycaemia except that an additional indwelling needle was inserted into the opposite antecubital vein to infuse hypertonic saline $(3 \% \mathrm{w} / \mathrm{v})$. After baseline samples of blood had been taken saline was infused at $0.1 \mathrm{ml} / \mathrm{kg} / \mathrm{min}$ via an Imed pump (Model 960, Imed, Milton Trading Estate, Abingdon, Oxford).

\section{Apomorphine test}

The procedure for taking blood samples was identical to that for the tests of anterior pituitary function. After the baseline samples had been taken $16 \mu \mathrm{g}$ of apomorphine was injected subcutaneously and further samples of blood taken at 5 minute intervals.

\section{Analyses}

All blood samples were collected into chilled plastico containers containing lithium heparin or fluoride for? glucose only. After mixing, samples were centrifuged at $4^{\circ} \mathrm{C}$ for 10 minutes at $2000 \mathrm{~g}$. Aliquots of fresh plasma were removed for estimation of sodium and glucose concentrations. Osmolality was measured by freezing point depression using an Advanced Digimatic Osmometer Model 3D. The remainder was frozen for hormone assays. AVP was extracted and assayed as previously described (Jenkins et al., 1984). Cortisol was measured by RIA using an Amerlex kit (Amersham). Glucose was estimated using a glucose oxidase method.

Table I Combined pituitary function test

\begin{tabular}{|c|c|c|c|c|c|c|c|}
\hline $\begin{array}{l}\text { Time } \\
\text { (min) }\end{array}$ & $\begin{array}{l}\text { Glucose } \\
\text { (mmol/l) }\end{array}$ & $\begin{array}{c}T S H \\
(m U / l)\end{array}$ & $\begin{array}{c}F S H \\
(m U / m l)\end{array}$ & $\begin{array}{c}L H \\
(m U / m l)\end{array}$ & $\begin{array}{c}G H \\
(m U / l)\end{array}$ & $\begin{array}{c}P R L \\
(m U / l)\end{array}$ & $\begin{array}{l}\text { Cortisol } \\
\text { (nmol/l) }\end{array}$ \\
\hline 0 & 3.3 & 2.5 & 3.5 & 5.0 & 2.2 & 115 & 577 \\
\hline 30 & 1.3 & 9.7 & 4.0 & 10.0 & 2.4 & 420 & 498 \\
\hline 60 & 3.4 & 8.5 & 4.5 & 9.5 & 32.0 & 250 & 1072 \\
\hline 90 & 4.0 & & & & 7.0 & 150 & 916 \\
\hline 120 & 4.0 & & & & 5.0 & & 657 \\
\hline
\end{tabular}

$\mathrm{T} 4=78 \mathrm{nmol} / \mathrm{l}$; testosterone $=14 \mathrm{nmol} / \mathrm{l}$. After time 0 samples, $0.15 \mathrm{U}$ soluble insulin $/ \mathrm{kg}, 200 \mu \mathrm{g}$ TRH and $100 \mu \mathrm{g} \mathrm{GnRH}$ were given i.v. $\mathrm{TSH}=$ thyroid stimulating hormone; $\mathrm{FSH}=$ follicle stimulating hormone; $\mathrm{LH}=$ luteinizing hormone; $\mathrm{GH}=\mathrm{growth}$ hormone; PRL = prolactin. 


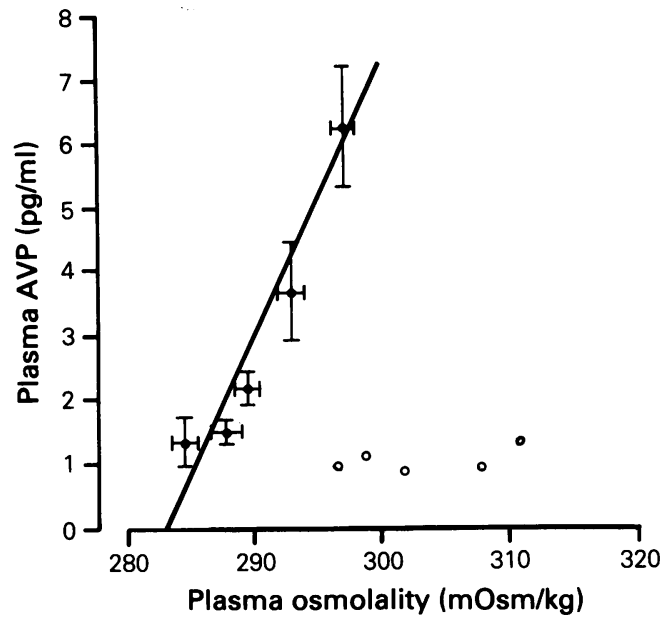

Figure 1 The relationship between plasma AVP and plasma osmolality during hypertonic saline infusion in the patient $(\mathrm{O})$ compared with that for control subjects (O) (mean \pm s.e.). For the normal subjects $(n=10)$ the regression line is given by the equation $y=0.36(x-283)$; $r=0.74, P<0.001$. For the patient the equation is $\mathrm{y}=0.005(\mathrm{x}-108) ; r=0.2, P$ not significant.

Human growth hormone (HGH) RIA utilized MRC hGH 69/46 iodinated by the iodogen method, 1st IRP 66/217 as standard and MRC antiserum at a final concentration of $1: 180,000$.

Human prolactin (HPRL) RIA was performed using materials supplied by NIADDK, iodination by the lactoperoxidase method and WHO 75/504 as standard.

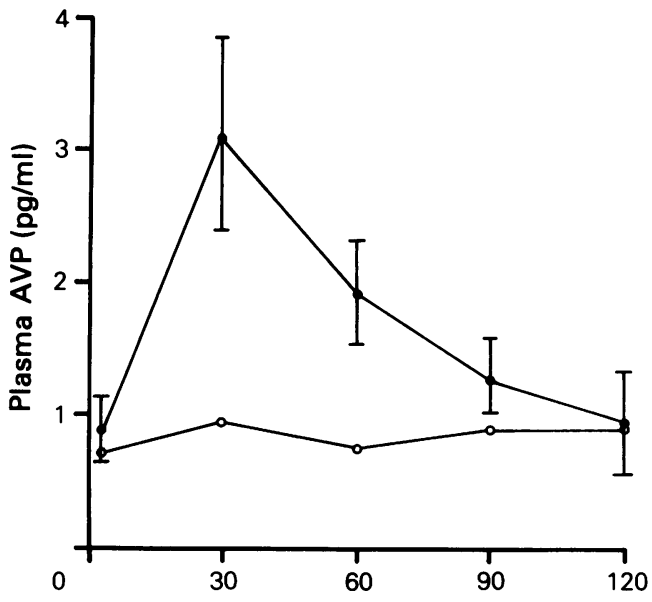

Figure 2 Response of plasma AVP to insulin-induced hypoglycaemia in the patient $(\mathrm{O}-\mathrm{O})$ compared with control subjects $\left(0-\frac{0}{0} n=10\right.$ mean \pm s.e.m.

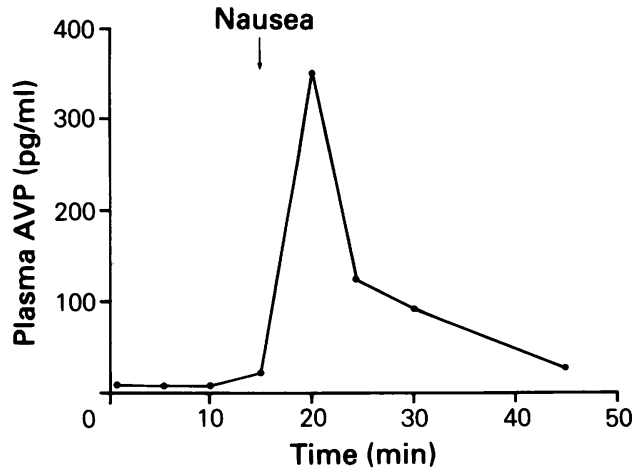

Figure 3 Response of plasma AVP to apomorphine.

HPLC of vasopressin was carried out as previously described (Ang \& Jenkins, 1984). Bioassay of extracted peptide was performed in the alcohol-anaesthetized rat (Bisset \& Chowdrey 1984).

\section{Results}

Anterior pituitary function was normal (Table I) but there was a deficient response of AVP to $3 \%$ saline infusion (Figure 1) and insulin (Figure 2). Regression analysis of the plasma AVP-plasma osmolality curves (Figure 1) showed a similar relationship to that found by Halter et al. (1977) for the normal subjects but no significant relationship for the patient. There was a rapid and large increase in plasma immunoreactive AVP after the subcutaneous injection of apomorphine (Figure 3). The immunoreactive AVP was shown to behave identically to synthetic AVP on HPLC (Figure 4 ) and was biologically active (Figure 5).

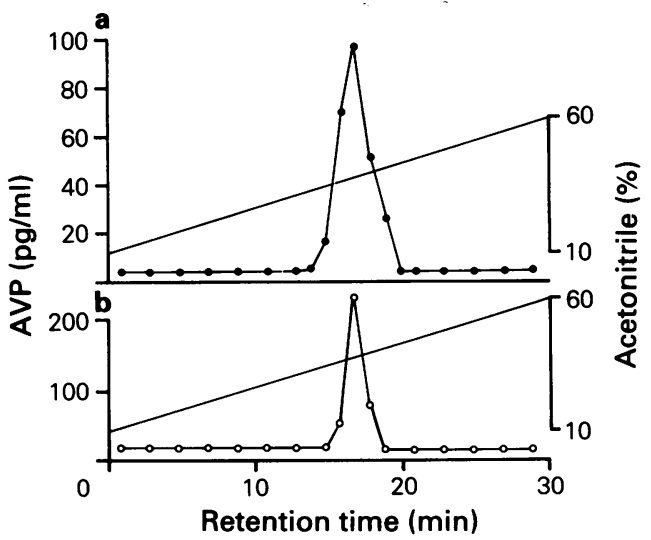

Figure 4 (a) Elution profile of apomorphine-stimulated AVP on reversed phase HPLC using $10-60 \%$ acetonitrile gradient. (b) Elution profile of synthetic AVP (Ferring) under identical conditions. 


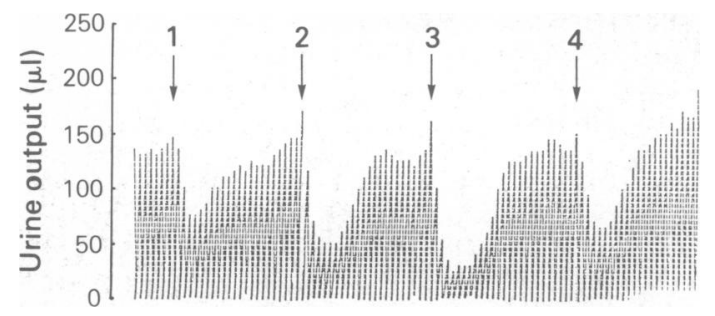

Figure 5 Bioassay of antidiuretic activity. Antidiuretic activity was assayed in the water-loaded, ethanolanaesthetized rat. Each vertical line represents the urine output in 1 minute. Intravenous injections were given at the arrows: $1(100 \mu \mathrm{l})$ and $3(200 \mu \mathrm{l})$ - extract of HPLC-purified immunoreactive material from plasma collected after apomorphine-induced nausea; $2(40 \mu \mathrm{U})$ AVP; $4(20 \mu \mathrm{U})$ AVP.

\section{Discussion}

The anterior hypothalamus is intimately involved in the control of water balance (Andersson, 1978), temperature (Cabanac, 1975; Satinoff, 1978) and plasma glucose (Frohman, 1983). Adipsic hypernatraemia may have a variety of pathological causes and has been distinguished from essential hypernatraemia (Robertson et al., 1982) though few studies have utilized dynamic studies of AVP release (Halter et al., 1977; Robertson, 1983). Regression analysis of the hypertonic saline test results suggests destruction of the osmoreceptor (Robertson, 1983). While it may be argued that the osmotic stimulus was not sufficient to exclude resetting of the osmostat (Gill et al., 1985) it may be noted that the patient demonstrated adipsia despite a plasma sodium of $187 \mathrm{mmol} / 1$ and plasma osmolality of $397 \mathrm{mOsm} / \mathrm{kg}$ in circumstances producing the syndrome of muscle weakness (Maddy \& Winternitz, 1971) and rhabdomyolysis (Opas et al., 1977).

Nausea is a potent non-osmotic stimulus to AVP release (Rowe et al., 1979) and a rapid and marked rise in plasma AVP was provoked by the apomorphine test. The physiological importance of this phenomenon is not yet known. It has been proposed that both osmotic and non-osmotic sensory information is fed into one unit which synthesizes and secretes AVP (Robertson, 1979). The apomorphine test result indicates that the pathway from the emetic centre to this unit was intact.

Of interest is the observation that insulin-induced hypoglycaemia caused a normal rise in GH and ACTH (as measured by plasma cortisol) but failed to stimulate AVP release suggesting a lesion between the glucose sensor and the AVP secretor unit but intact pathways in the regulation of GH and ACTH secretion.

Amico et al. (1985) have recently demonstrated the importance of the characterization of immunoreactive neurohypophysial peptides. In view of this we showed that the AVP immunoreactive material secreted in response to apomorphine behaved identically to the synthetic peptide on HPLC and was biologically active.

Chronic hypothermia was documented over a period of 4 years. Formal tests of temperature regulation were not performed but it is evident that the patient demonstrated loss of the ability to control heat conservation by both behavioural (e.g. seeking a warm room or clothing) and physiological mechanisms at least down to a central temperature of $30^{\circ} \mathrm{C}$. The available data do not allow us to distinguish between a lesion causing regulation around a lower set-point and one causing failure of mechanisms of heat conservation (Hockaday et al., 1962).

Thrombocytopenia is considered to occur in hyचق pothermia as a result of splenic pooling and is noted in? hibernating animals and patients undergoing hypothermic cardiac surgery (Aster, 1983): it may play a role in the pathology of neonatal cold injury (Cohen et al., 1984). After rewarming the thrombocytopenia did not recur and there were no clinical features to suggest another cause.

\section{Acknowledgements}

SSN is a Wellcome Lecturer. We wish to thank the Wellcome Trust and St. George's Hospital Research Committee for financial support. We are indebted to Dr H.S. Chowdrey, Department of Pharmacology, St. Thomas' Hospital Medical School for performing the bioassays.

\section{References}

AMICO, J.A., ERVIN, M.G., LEAKE, R.D., FISHER, D.A., FINN, F.M. \& ROBINSON, A.G. (1985). A novel oxytocinlike and vasotocin-like peptide in human plasma after administration of estrogen. Journal of Clinical Endocrinology and Metabolism, 60, 5.

ANDERSSON, B. (1978). Regulation of water intake. Physiological Reviews, 58, 582.

ANG, V.T.Y. \& JENKINS, J.S. (1984). Neurohypophysial hormones in the adrenal medulla. Journal of Clinical Endocrinology and Metabolism, 58, 688.

ASTER, R.H. (1983). Thrombocytopenia due to sequestration of platelets. In Hematology Williams, W.J., Beutler, E., Erslev, A.J. \& Lichtman, M.A. (eds), 3rd edition. pp. 1338-1349. McGraw-Hill: New York. 
BISSET, G.W. \& CHOWDREY, H.S. (1984). A cholinergic link in the reflex release of vasopressin by hyoptension in the rat. Journal of Physiology (London), 354, 523.

CABANAC, M. (1975). Temperature regulation. Annual Review of Physiology, 37, 415.

COHEN, I.J., AMIR, J., GEDALIAH, A., RACHMAL, A., GORODISCHER, R. \& ZAIZOF, R. (1984). Thrombocytopenia of neonatal cold injury. Journal of Pediatrics, $104,620$.

CROMPTON, M.R. (1963). Hypothalamic lesions following the rupture of cerebral berry aneurysms. Brain, 86, 301.

FROHMAN, L.A. (1983). CNS peptides and glycoregulation. Annual Review of Physiology, 45, 95.

GILL, P., BAYLIS, P. \& BURN, J. (1985). A case of 'essential' hypernatraemia due to resetting of the osmostat. Clinical Endocrinology (Oxford), 22, 545.

HALTER, J.B., GOLDBERG, A.P., ROBERTSON, G.L. \& PORTE, D., JR. (1977). Selective osmoreceptor dysfunction in the syndrome of chronic hypernatremia. Journal of Clinical Endocrinology and Metabolism, 44, 609.

HOCKADAY, T.D.R., CRANSTON, W.I., COOPER, K.E. \& MOTTRAM, R.F. (1962). Temperature regulation in chronic hypothermia. Lancet, ii, 428.

JENKINS, J.S., ANG, V.T.Y., HAWTHORN, J., ROSSOR, M.N. \& IVERSEN, L.L. (1984). Vasopressin, oxytocin and neurophysins in the human brain and spinal cord. Brain Research, 291, 111.

MADDY, J.A. \& WINTERNITZ, W.W. (1971). Hypothalamic syndrome with hypernatremia and muscular paralysis.
American Journal of Medicine, 51, 394.

OPAS, L.M., ADLER, R., ROBINSON, R. \& LIEBERMAN, E. (1977). Rhabdomyolysis with severe hypernatremia. Journal of Pediatrics, 90, 713.

PLUM, F. \& VAN UITERT, R. (1978). Nonendocrine diseases and disorders of the hypothalamus. In The Hypothalamus, Reichlin, S., Baldessarini, R.J. \& Martin, J.B. (eds). pp. 415-475. Raven Press: New York.

ROBERTSON, G.L. (1979). The physiopathology of ADH secretion. In Clinical Neuroendocrinology: A Pathophysiological Approach, Tolis, G., Labrie, F., Martin, J.B. \& Naftolin, F. (eds). pp. 247-260. Raven Press: New York.

ROBERTSON, G.L., AYCINENA, P. \& ZERBE, R.L. (1982). Neurogenic disorders of osmoregulation. American Journal of Medicine, 72, 339.

ROBERTSON, G.L. (1983). Thirst and vasopressin function in normal and disordered states of water balance. Journal of Laboratory and Clinical Medicine, 101, 351.

ROWE, J.W., SHELTON, R.L., HELDERMAN, J.H., VESTAL, R.E. \& ROBERTSON, G.L. (1979). Influence of the emetic reflex on vasopressin release in man. Kidney International, 16, 729.

SATINOFF, E. (1978). Neural organisation and evolution of thermal regulation in mammals. Science, 201, 16.

TAKAKU, A., SHINDO, K., TANAKA, S., MORI, T. \& SUZUKI, J. (1979). Fluid and electrolyte disturbances in patients with intracranial aneurysms. Surgical Neurology (New York), 11, 349. 